\title{
Insights on Mycoremediation of Contaminated Soil with Kerosene
}

\author{
Suman Sasmita Dash ${ }^{1}$, Jyotsna Gawai ${ }^{2}$, Rishi Dewangan ${ }^{3}$, Sudhanshu Singh ${ }^{* 4}$ \\ ${ }^{1}$ Central University of Punjab, Bathinda, India; \\ 2 R.T.M. Nagpur University, Nagpur, India. \\ 3,4 Amity University Rajasthan, Jaipur, India; *e-mail : singhs1183@gmail.com
}

\begin{abstract}
Bioremediation of hydrocarbon contaminated soil is inexpensive and involves complete mineralization of organic contaminants to simple organic compounds, carbon dioxide, water and other inorganic compounds by the action of biological agents, according to their metabolic capacities.

Key Words: Bioremediation, Contaminants, Microbial population.

SAM RIDDHI : A Journal of Physical Sciences, Engineering and Technology, (2021); DOI : 10.18090/samriddhi.v13iS1.2
\end{abstract}

\section{INTRODUCTION BACKGROUND}

$T$

he susceptibility of hydrocarbons to be degraded by microorganisms (linear alkanes $>$ branched alkanes $>$ small aromatic compounds $>$ cyclic alkanes $>$ polycyclic aromatic hydrocarbons) is one of the limiting factor for biodegradation. Soil fungi have been reported with efficiency of biodegradation of $6 \%$ to $82 \%$ while soil bacteria [2] and marine have biodegradation efficiency of $0.13-50 \%$ and $0.003-100 \%$ respectively [3]. The fungal oxidation of hydrocarbon compounds employees' monooxygenase enzyme that leads to formation of trans-diol. Rhizopusutilize kerosene as carbon source. Kerosene is majorly composed of aliphatic hydrocarbons (65-70\%), benzene derivatives (10-15\%) and naphthalene derivatives, with $\mathrm{C} 9-\mathrm{C} 16$ compounds. Also there are great and vital roles of engineering nanomaterials in this work [9].

\section{EXPERIMENTAL METHODOLOGY}

The fungi were pre-cultured in an air-tight container for about 7days using approximately $30 \mathrm{~g}$ of bread pieces as substrate, i.e. moistened with potato broth.

The same method was repeated for the soil sample taken out after 5, 10 and 15days of the treatment with the fungus. After 5 days of germination, the plant height, average leaf length, average leaf
Corresponding Author: Sudhanshu Singh, Amity University Rajasthan, Jaipur, India; *e-mail : singhs1183@gmail.com

How to cite this article : Dash, Suman, S., Gawai, J., Dewangan, R., Singh, S. (2021). Insights on Mycoremediation of Contaminated Soil with Kerosene. SAMRIDDHI : A Journal of Physical Sciences, Engineering and Technology, Volume 13, Special Issue (1), 4-6.

\section{Source of support : Nil \\ Conflict of interest : None}

width was measured using scale. To obtain fresh weight, after washing and cleaning properly, the plant was put in a zipper bag and was weighed.

\section{Measurement of $\mathrm{pH}$}

Two samples of soil were taken from the contaminated soil of equal amount in two separate containers. To one soil sample, $10 \mathrm{ml}$ of vinegar was added and was studied for its reaction. To other soil sample, $10 \mathrm{ml}$ of baking soda solution was added and was observation for the reaction.

\section{AIN FINDINGS}

The growth ability of Rhizopus on hydrocarbon contaminated soil was indirectly measured by monitoring its growth promoting capacity on the treated soil. The seed germinated in case of the

CThe Author(s). 2021 Open Access This article is distributed under the term of the Creative Commons Attribution 4.0 International License (http://creativecommons.org/ licenses/by/4.0/), which permits unrestricted use, distribution, and non-commercial reproduction in any medium, provided you give appropriate credit to the original author(s) and the source, provide a link to the Creative Commons license, and indicate if change were made. The Creative Commons Public Domain Dedication waiver (http:/ /creativecommons.org/publicdomain/zero/1.0) applies to the data made available in this article, unless otherwise stated. 
soil sample taken out after 5 days of mycoremediation, but failed to develop further and died. This showed that adequate mycoremediation did not occur until 5 days; to promote the growth of seed. The root system was well developed [figure 3]. For the control group, seed was germinated within $24 \mathrm{~h}$ of plantation. The study showed that approximately $90 \%$ of hydrocarbon contaminants in the soil were degraded by Rhizopus, allowing ample growth of Vignaradiata plant.

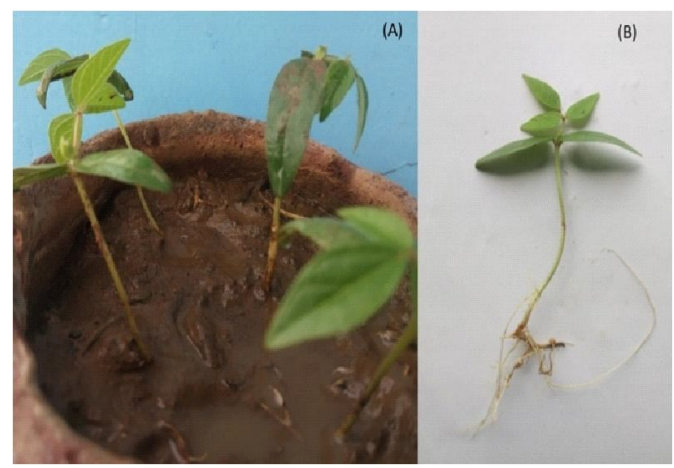

Figure 1: Control Group plant (A) plant height (B) Root system

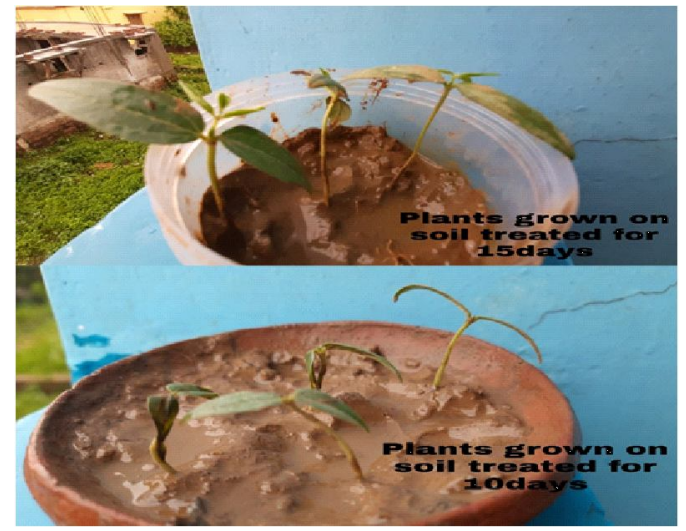

Figure 2: Effect of mycoremediation on growth of Vignaradiataafter 10 and 15 days of treatment

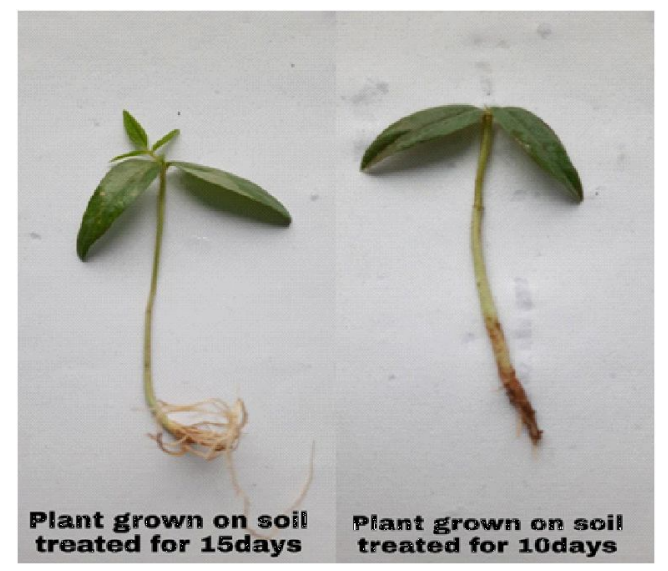

Figure 3: Effect of hydrocarbon contamination on the root system after 15 days and 10 days of mycoremediation
The control soil sample didn't show any reaction in both baking soda and vinegar solution, thus it can be said to be at neutral pH. The soil sample taken out after 15days of mycoremediation did no fizzing reaction to both vinegar and baking soda solution, showing that the $\mathrm{pH}$ was restored to neutral due to effective mycoremediation process.

Biodegradation of kerosene constituents by Rhizopus made the soil suitable for plant growth, as observed from the $\mathrm{pH}$ measurement of the soil sample. The fungal degradation efficiently occurs within 15days of treatment, facilitating the optimal growth of Vignaradiata plant.

\section{CONCLUSION}

Rhizopus was competent of overwhelming carbon. The information obtain in the current search proceed our information of kerosene conflict of the fungi. It also might create gifted candidate for additional study concerning their skill to take away kerosene as of infected environment.

\section{References}

[1] Ti,, R., Arumugam, K., Nagasathya, A., Thajuddin, N., \& Paneerselvam, A. (2013). Studies on mycoremediation of used engine oil contaminated soil samples. Advances in Applied Science Research, 4(2), 110-118..

[2] Dickson, U. J., Coffey, M., M ortimer, R. J. G., Di Bonito, M., \& Ray, N. (2019). $M$ ycoremediation of petroleum contaminated soils: Progress, prospects and perspectives. Environmental Science: Processes \& Impacts, 21(9), 1446-1458..

[3] Bhat, M. M., Kumar, D., Narain, K., Shukla, R. N., \& Yunus, M. (2011). Mycoremediation of hydrocarbon contaminated soil-FTIR based analysis. World Appl. Sci. J, 15(11), 1547-1552..

[4] Bosco, F., \& Mollea, C. (2019). Mycoremediation in soil. Environ. Chem. Recent Pollut. Control. Approaches.5. Mutambu, M arshall, et al. "Insitu mycoremediation of mine dumps soil contaminated with petroleum hydrocarbons: FTIR based analysis." (2017).

[5] Thakur, M. (2019). M ushrooms as a biological tool in mycoremediation of polluted soils. 
In Emerging Issues in Ecology and Environmental Science (pp. 27-42). Springer, Cham.

[6] Gupta, S., \& Pathak, B. (2020). Mycoremediation of polycyclic aromatic hydrocarbons. In Abatement of Environmental Pollutants (pp. 127-149). Elsevier.

[7] Greco, G., Di Piazza, S., Cecchi, G., Cutroneo, L., Capello, M., \& Zotti, M. (2019). Mycoremediation of Oily Slime Containing a Polycyclic Aromatic Hydrocarbon Mixture.
Waste and Biomass Valorization, 10(12), 38213831..

[8] Chikere, C. B., \& Azubuike, C. C. (2014). Characterization of hydrocarbon utilizing fungi from hydrocarbon polluted sediments and water. Nigerian Journal of Biotechnology, 27, 49-54.

[9] Singh, Sudhanshu, et al. (2017). "Preparation and Characterization of Barium Titanate Composite Film". Materials Today: Proceedings 4.2: 3300-3307. 